\title{
Subthalamic Nucleus Neurons Switch from Single-Spike Activity to Burst-Firing Mode
}

\author{
Corinne Beurrier, ${ }^{1}$ Patrice Congar, ${ }^{2}$ Bernard Bioulac, ${ }^{1}$ and Constance Hammond ${ }^{3}$ \\ 1 Université de Bordeaux II, Centre National de la Recherche Scientifique Unitié Mixte de Recherche 5543, 33076 \\ Bordeaux cédex, France, 2Université René Descartes, Institut National de la Santé et de la Recherche Médicale U 29, \\ 75674 Paris cédex 14, France, and ${ }^{3}$ Centre Paul Broca, Institut National de la Santé et de la Recherche Médicale U 159 , \\ 75014 Paris, France
}

The modification of the discharge pattern of subthalamic nucleus (STN) neurons from single-spike activity to mixed burstfiring mode is one of the characteristics of parkinsonism in rat and primates. However, the mechanism of this process is not yet understood. Intrinsic firing patterns of STN neurons were examined in rat brain slices with intracellular and patch-clamp techniques. Almost half of the STN neurons that spontaneously discharged in the single-spike mode had the intrinsic property of switching to pure or mixed burst-firing mode when the membrane was hyperpolarized from $-41.3 \pm 1.0 \mathrm{mV}$ (range, -35 to $-50 \mathrm{mV} ; n=15$ ) to $-51.0 \pm 1.0 \mathrm{mV}$ (range, -42 to -60 $\mathrm{mV} ; n=20)$. This switch was greatly facilitated by activation of metabotropic glutamate receptors with $1 S, 3 R-A C P D$. Recurrent membrane oscillations underlying burst-firing mode were endogenous and $\mathrm{Ca}^{2+}$-dependent because they were largely reduced by nifedipine $(3 \mu \mathrm{M}), \mathrm{Ni}^{2+}(40 \mu \mathrm{M})$, and BAPTA-AM
(10-50 $\mu \mathrm{M})$ at any potential tested, whereas TTX $(1 \mu \mathrm{M})$ had no effect. In contrast, simultaneous application of TEA (1 mM) and apamin $(0.2 \mu \mathrm{M})$ prolonged burst duration. Moreover, in response to intracellular stimulation at hyperpolarized potentials, a plateau potential with a voltage and ionic basis similar to those of spontaneous bursts was recorded in $82 \%$ of the tested STN neurons, all of which displayed a low-threshold $\mathrm{Ni}^{2+}$ sensitive spike. We propose that recurrent membrane oscillations during bursts result from the sequential activation of T/Rand L-type $\mathrm{Ca}^{2+}$ currents, a $\mathrm{Ca}^{2+}$-activated inward current, and $\mathrm{Ca}^{2+}$-activated $\mathrm{K}^{+}$currents.

Key words: tonic and bursting activities of STN neurons in slices; burst ionic mechanisms; low-threshold spike; $\mathrm{Ca}^{2+}$ dependent plateau potential; intracellular and patch-clamp recordings; Parkinson's disease
The subthalamic nucleus (STN) is composed of glutamatergic neurons that control the circuitry of the basal ganglia by modulating the activity of the two principal output structures of the network: the internal pallidal segment and the substantia nigra pars reticulata (for review, see Albin et al., 1989; DeLong, 1990; Parent and Hazrati, 1995; Mink, 1996; Féger et al., 1997). The importance of this control is exemplified by the various consequences of STN lesion in both control animals and animal models of Parkinson's disease.

Electrolytic lesions of the STN in normal monkeys produce a hyperkinetic syndrome (Whittier and Mettler, 1949). This has also been reproduced by toxic lesions restricted to the STN, sparing the fibers of passage (Hammond et al., 1979; Hamada and DeLong, 1992), transient pharmacological blockade of STN activity (Crossman et al., 1984), and high-frequency STN stimulation (Beurrier et al., 1997). All these observations reflect the importance of the control exerted by the STN in control animals and provide an explanation for the violent, involuntary move-

\footnotetext{
Received Oct. 13, 1998; accepted Oct. 29, 1998.

This work was supported by grants from Centre National de la Recherche Scientifique, Fondation pour la Recherche Médicale, Conseil Régional d'Aquitaine, and Université de Bordeaux II. C.B. has a scholarship from Ministère de l'Enseignement Supérieur et de la Recherche (French Ministry of Research and Higher Education) and from the Lilly Institute. We thank S. Olliet and A. Taupignon for their comments on this manuscript, J. Audin, R. Bonhomme, J. M. Calvinhac, and G. Gaurier for technical assistance. Outstanding thanks to J. M. Israel.

Correspondence should be addressed to Corinne Beurrier, Université de Bordeaux II, Centre National de la Recherche Scientifique Unité Mixte de Recherche 5543, 146 rue Léo Saignat, 33076 Bordeaux cédex, France.

Copyright (ㄷ) 1999 Society for Neuroscience $0270-6474 / 99 / 190599-11 \$ 05.00 / 0$
}

ments of the contralateral limbs (termed "hemiballism") that occur in STN-lesioned humans (Martin, 1927; Bathia and Marsden, 1994). Manipulating STN neurons in animal models of Parkinson's disease leads to a very different consequence. In monkeys treated with the neurotoxic 1-methyl-4-phenyl-1,2,3,6tetrahydropyridine (MPTP), STN lesion (Bergman et al., 1990; Aziz et al., 1991; Guridi et al., 1996), pharmacological blockade of the subthalamopallidal pathway (Graham et al., 1990; Brotchie et al., 1991), or high-frequency stimulation of the STN (Benazzouz et al., 1993), produce a reduction in motor impairments. These results suggest that STN constitutes a good therapeutic target for the treatment of Parkinson's disease. For this reason, highfrequency stimulation of the STN is being performed in several patients suffering from severe parkinsonism and gives very consistent results (Limousin et al., 1995).

To understand how the activity of STN neurons can regulate the operational mode of basal ganglia, it is essential to determine in detail the electrical properties of STN neurons and the underlying ionic mechanisms in physiological conditions in vitro. Previous studies have described the responses of STN neurons to intracellular current pulses (Nakanishi et al., 1987; Overton and Greenfield, 1995; Overton et al., 1995; Plenz et al., 1997). However, their ionic basis, as well as those of spontaneous firing patterns, have not been fully characterized. We now report, with the use of intracellular and patch-clamp techniques in rat brain slices, that a substantial proportion of STN neurons can shift from a regular single-spike mode to a burst-firing mode. We have analyzed the intrinsic membrane properties underlying this prop- 
erty and propose that this electrical behavior provides a cellular substrate for the functional role of the STN in controlling movements under normal and altered conditions.

\section{MATERIALS AND METHODS}

Slice preparation. Experiments were performed on STN neurons in slices obtained from 20- to 28-d-old male Wistar rats. Rats were anesthetized with ether and decapitated. The brain was quickly removed, and a block of tissue containing the STN was isolated on ice in a $0-5^{\circ} \mathrm{C}$ oxygenated solution containing (in mM): $1.15 \mathrm{NaH}_{2} \mathrm{PO}_{4}, 2 \mathrm{KCl}, 26 \mathrm{NaHCO}_{3}, 7$ $\mathrm{MgCl}_{2}, 0.5 \mathrm{CaCl}_{2}, 11$ glucose, and 250 saccharose, equilibrated with $95 \% \mathrm{O}_{2}$ and $5 \% \mathrm{CO}_{2}, \mathrm{pH}$ 7.4. This cold solution, with a low $\mathrm{NaCl}$ and $\mathrm{CaCl}_{2}$ content, improved tissue viability. In the same medium, 300- to $400-\mu \mathrm{m}$-thick coronal slices were prepared using a Vibratome (Campden Instruments LTD, Loughborough, UK) and were then incubated at room temperature in a Krebs' solution containing (in $\mathrm{mM}$ ): $124 \mathrm{NaCl}, 3.6 \mathrm{KCl}$, 1.25 HEPES, $26 \mathrm{NaHCO}_{3}, 1.3 \mathrm{MgCl}_{2}, 2.4 \mathrm{CaCl}_{2}$, and 10 glucose, equilibrated with $95 \% \mathrm{O}_{2}$ and $5 \% \mathrm{CO}_{2}, \mathrm{pH}$ 7.4. After a $2 \mathrm{hr}$ recovery period, STN slices were transferred one at a time to an interface-type recording chamber, maintained at $30 \pm 2^{\circ} \mathrm{C}$ and continuously superfused (1-1.5 $\mathrm{ml} /$ minute) with the oxygenated Krebs' solution.

Electrophysiological recordings. Slices were visualized using a dissecting microscope, and the recording electrode was precisely positioned in the STN. Electrophysiological recordings of STN neurons were performed in current-clamp mode using the intracellular or patch-clamp technique. Signals were recorded using an Axoclamp 2A (Axon Instruments, Foster City, CA) in bridge or continuous single-electrode voltage-clamp mode for intracellular and patch-clamp experiments, respectively.

For intracellular recordings, microelectrodes were pulled from filamented borosilicate glass (BF-100-50-10; Sutter Instruments, Novato,
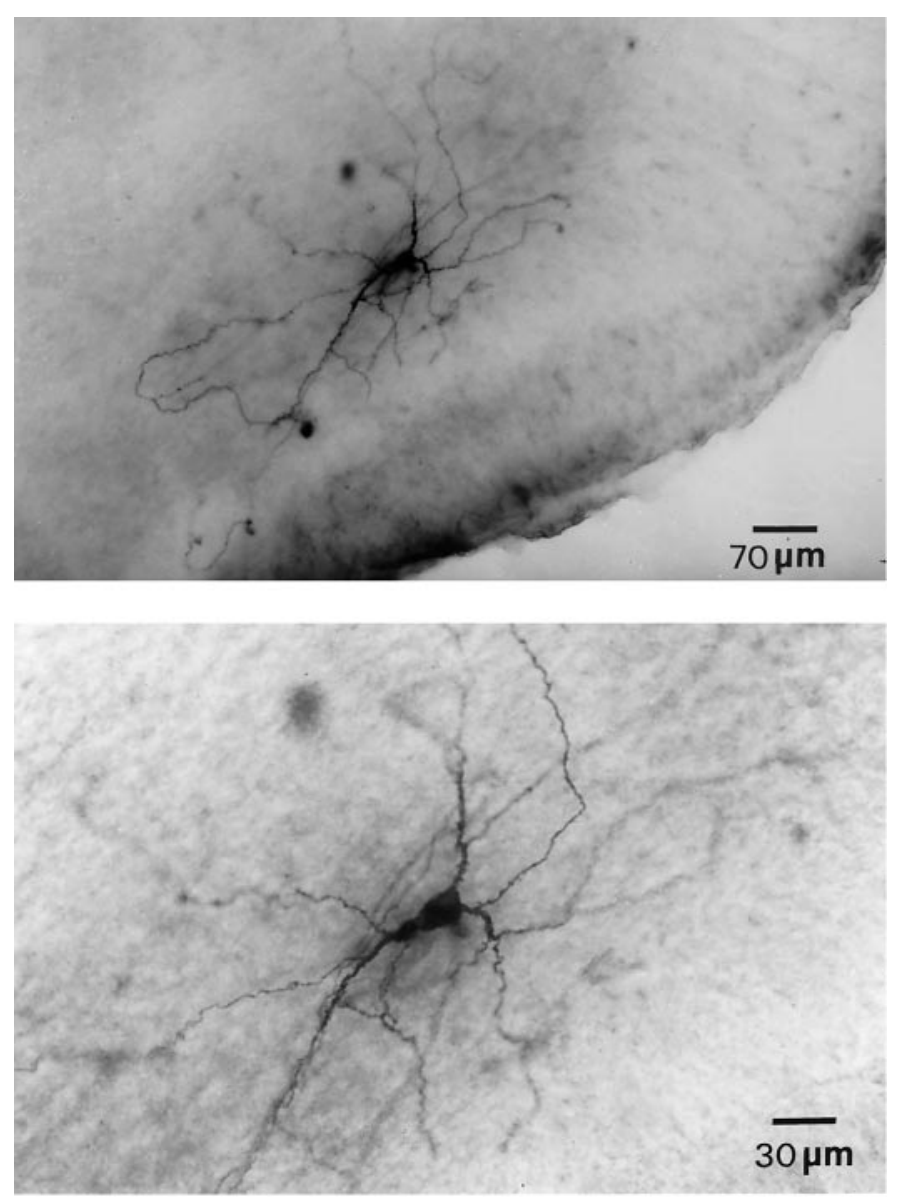

Figure 1. Microphotographs of a biocytin-filled STN neuron at two magnifications. The labeled neuron is located within the boundaries of the STN (top) and presents a dense dendritic arborization (top) and numerous spines on dendrites (bottom).
A

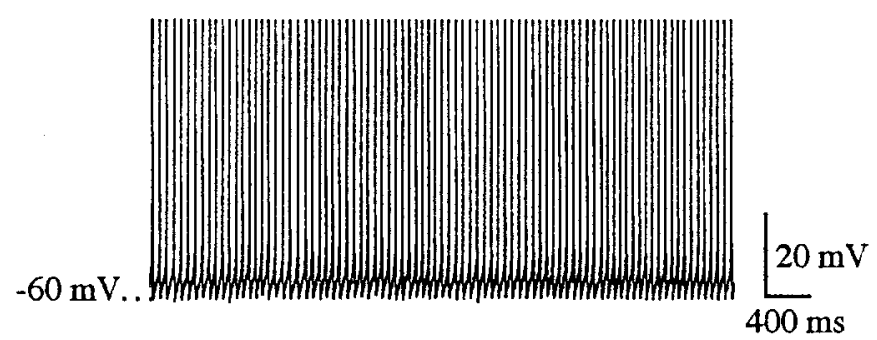

B
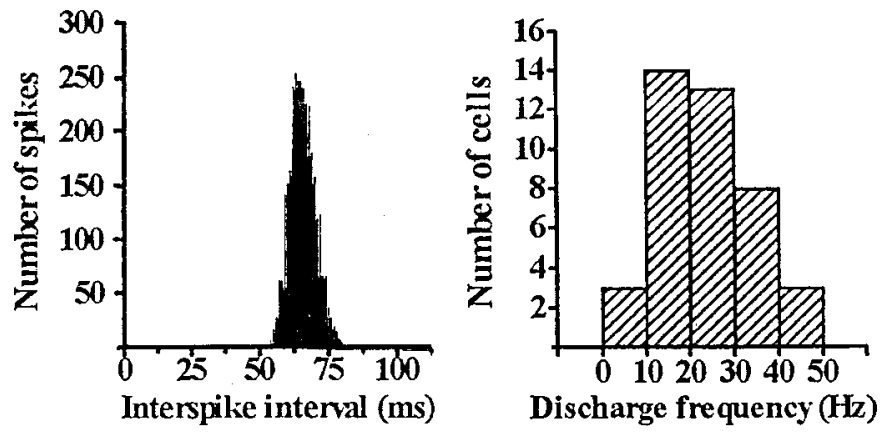

Figure 2. Single-spike mode. $A$, Tonic and regular activity (single-spike mode) of an STN neuron, recorded with intracellular techniques at resting membrane potential and $(B)$ corresponding interspike interval histogram (mean interval, $66.1 \pm 15.6 \mathrm{msec}$; bin width, $12.5 \mathrm{msec}$ ). $C$, Discharge frequency histogram of single-spike mode recorded in 41 STN neurons (mean frequency, $22.3 \pm 1.5 \mathrm{~Hz}$; bin width, $10 \mathrm{~Hz}$ ). Spikes in $A$ are truncated.

CA) on a horizontal Flaming-Brown micropipette puller (P-87; Sutter Instruments). They had a resistance of $150-200 \mathrm{M} \Omega$ when filled with $2 \mathrm{M}$ potassium acetate. For patch-clamp experiments, recordings were made using the blind patch-clamp technique in the cell-attached or whole-cell configuration. Patch electrodes were pulled from filamented borosilicate thin-wall glass capillaries (GC150F-15; Clarck Electromedical Instruments, Pangbourne, UK) with a vertical puller (LM-3P-A; List Instruments, Darmstadt-Eberstad, Germany) and had a resistance of 10-12 $\mathrm{M} \Omega$ when filled with (in $\mathrm{mM}$ ): $120 \mathrm{Kgluconate}, 10 \mathrm{KCl}, 10 \mathrm{NaCl}, 10$ EGTA, $10 \mathrm{HEPES}, 1 \mathrm{CaCl}_{2}, 2 \mathrm{MgATP}$, and $0.5 \mathrm{GTP}, \mathrm{pH} 7.25$.

Drugs. All drugs were purchased from Sigma (St. Louis, MO), except $1 S, 3 R$-1-aminocyclopentane-1,3-dicarboxylate ( $1 S, 3 R$-ACPD) purchased from Tocris Cookson (Bristol, UK) and tetrodotoxin (TTX) and apamin purchased from Latoxan (Rosans, France). Biocytin and 1,2-bis(2aminophenoxy)-ethane- $N, N, N^{\prime}, N^{\prime}$-tetraacetic acid (BAPTA) were diluted in the pipette solutions. All other drugs were diluted in the oxygenated Krebs' solution and applied through this superfusion medium. Nifedipine and BAPTA-AM were dissolved in dimethylsulfoxide (final concentration, $0.03-0.5 \%)$. For experiments with cobalt $\left(\mathrm{Co}^{2+}\right)$, calcium $\left(\mathrm{Ca}^{2+}\right)$-free $\left(\mathrm{Ca}^{2+}\right.$ was substituted for equimolar concentration of $\mathrm{Co}^{2+}$ ) or low $\mathrm{Ca}^{2+}$ solutions $\left(0.4 \mathrm{~mm}\right.$ with $\left.2 \mathrm{mM} \mathrm{Co}^{2+}\right)$ were used.

Histology. In some experiments, recordings were performed with pipette solution containing biocytin $(0.5-1 \%)$ to allow the subsequent identification and morphological analysis of the recorded neurons. The avidin-biotinylated horseradish peroxidase (ABC complex) reaction was used to visualize the biocytin-filled neurons. After recording, slices were fixed for $1-2 \mathrm{~d}$ in a solution containing $4 \%$ paraformaldehyde and $0.15 \%$ picric acid in phosphate buffer $(0.1 \mathrm{M}, \mathrm{pH} 7.4)$ at $4^{\circ} \mathrm{C}$. After several rinsings in Tris-buffered saline (TBS; $0.05 \mathrm{M}, \mathrm{pH} 7.4$ ), the sections were treated with a mixture of methanol and $\mathrm{H}_{2} \mathrm{O}_{2}$ for $30 \mathrm{~min}$, rinsed again in TBS, and processed for 2 or $3 \mathrm{~d}$ with the standard $\mathrm{ABC}$ complex 


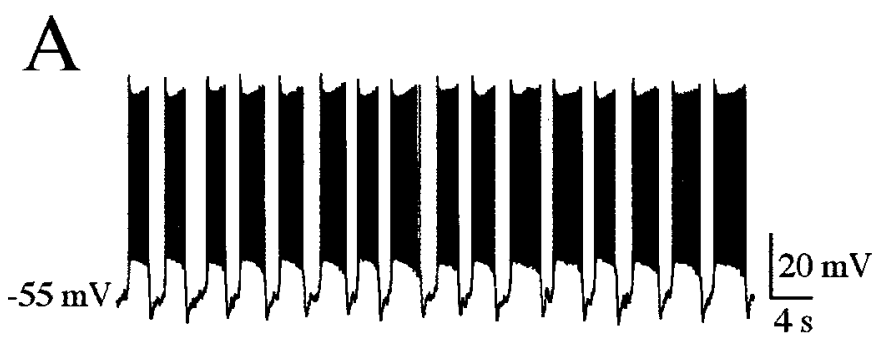

B

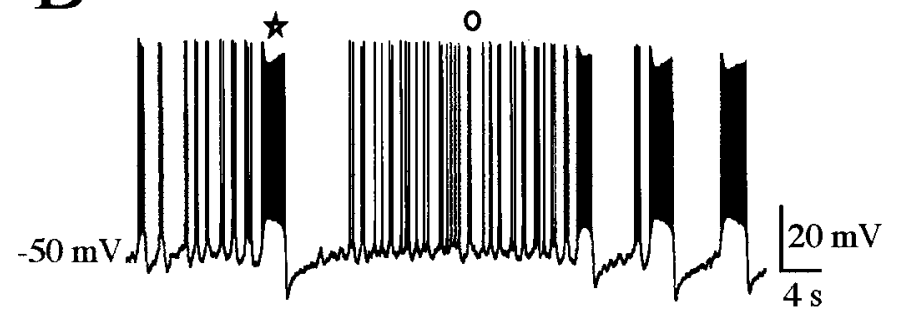

C

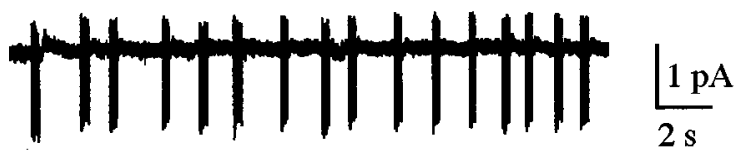

Figure 3. Burst-firing mode. Two types of burst mode recorded with patch-clamp techniques in two different STN neurons: pure burst mode $(A)$ and mixed burst mode $(B)$, consisting of long bursts ( ( $)$ ) separated by sequences of short bursts $(O)$. $C$, Spontaneous bursts recorded in the cell-attached configuration in voltage-clamp mode.

(Vectastain ABC kit, Vector laboratories, Burlingame, CA) at $4^{\circ} \mathrm{C}$. After several washes in TBS, sections were treated with diaminobenzidine as a chromogen and $\mathrm{H}_{2} \mathrm{O}_{2}$ for 5-10 min (DAB substrate peroxidase kit; Vector Laboratories). The sections were then rinsed several times in TBS, dehydrated and rehydrated in graded ethanol, stained with cresyl violet, dehydrated again in graded ethanol, cleared in xylene, and mounted in Eukitt (053-47505; Labonord, Villeneuve d'Ascq, France).

Data analysis. Current and voltage outputs were displayed simultaneously on a storage oscilloscope and a four-channel chart recorder (Gould Instruments, Longjumeau, France), digitized (DR-890; NeuroData Instruments, New York, NY), and stored on a videotape for subsequent off-line analysis with pClamp6 software (Axon Instruments). Values are expressed as mean \pm SEM. Statistical significance was assessed using the Student's $t$ test (unpaired data). Parameters of the single-spike and bursting modes were quantified from intracellular and patch-clamp recordings, respectively.

\section{RESULTS}

\section{Morphology and passive membrane properties of STN neurons}

Results were obtained from 141 STN neurons. The soma of biocytin-filled recorded neurons $(n=5)$ were all located within the boundaries of the STN identified with the cresyl violet staining technique (Fig. 1A). Soma had diameters of 10-25 $\mu \mathrm{M}$ and gave rise to four or five dendritic trunks (Fig. $1 B$ ). Axons gave rise to numerous collaterals. Only neurons with an input membrane resistance $>100 \mathrm{M} \Omega$, firing action potentials with an amplitude of at least $50 \mathrm{mV}$, and an afterhyperpolarizing potential (AHP) at a threshold of $-50 \mathrm{mV}$, were included in the present study. The resting potential of spontaneously firing neurons was difficult to establish because of the absence of a stable membrane potential. The input resistance of STN neurons was $200.2 \pm 6.8$ $\mathrm{M} \Omega(n=88)$ and not significantly different when measured with both the patch-clamp and intracellular techniques $(p=0.36$; $n=88$ ).

\section{Firing patterns of STN neurons: single-spike and burst-firing modes}

All tested STN neurons $(n=83)$ displayed a tonic discharge of single spikes (Fig. 2, single-spike mode) that totally disappeared in the presence of TTX ( $1 \mu \mathrm{M}, n=33$ of 33, data not shown). Among STN neurons, $46 \%(n=38$ of 83$)$ were also able to fire in bursts (burst-firing mode, Fig. 3). These STN neurons switched from one mode to the other depending on membrane potential (Fig. 4). Single-spike mode was recorded at membrane potentials between -35 and $-50 \mathrm{mV}(-41.3 \pm 1.0 \mathrm{mV} ; n=15)$, whereas burst firing was present in the membrane potential range of -42 to $-60 \mathrm{mV}(-51.0 \pm 1.0 \mathrm{mV} ; n=20)$ (Fig. 4). These values represent the threshold potential of spikes in the single-spike mode (Table 1, parameter 3 ) and that of bursts in the burst-firing mode (Table 2, parameter 1). At membrane potentials more hyperpolarized than -60 to $-70 \mathrm{mV}$, most STN neurons were silent (Fig. 4). At membrane potentials more depolarized than $-30 \mathrm{mV}$, spike amplitude decreased, and spike frequency increased, leading rapidly to a blockade of STN tonic activity. Activation of group I and II metabotropic glutamate receptors (I-IImGluRs) by $1 S, 3 R$-ACPD (25 $\mu \mathrm{M})$ (Nakanishi, 1994; Pin and

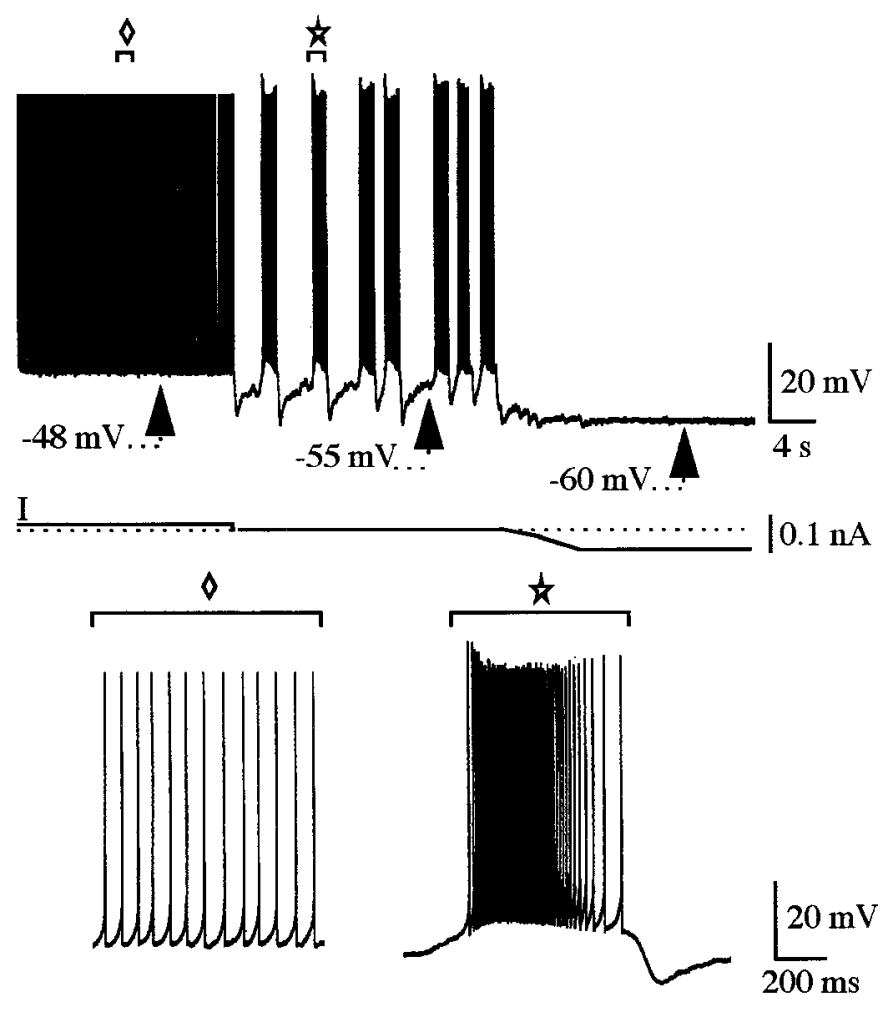

Figure 4. Switch of firing mode according to membrane potential. Pure burst mode (is) was triggered at resting membrane potential $(I=0$, dotted line, middle) in a whole-cell-recorded neuron that displayed the singlespike mode $(\diamond)$ at a more depolarized membrane potential $(I=+0.2 \mathrm{nA}$, left $)$. At a more hyperpolarized potential $(I=-0.6 \mathrm{nA}$, right $)$, the cell became silent. The two bottom traces are taken from the above records and displayed at an expanded time scale. Spikes of the single-spike mode in the left part are truncated. 
Table 1. Quantitative parameters of the single-spike mode

\begin{tabular}{lccl} 
& Mean \pm SEM & Range & Number of cells \\
\hline Discharge frequency $(\mathrm{Hz})$ & $22.3 \pm 1.5$ & $5 / 43$ & $n=41$ \\
1. Spike amplitude $(\mathrm{mV})$ & $74.7 \pm 1.1$ & $57 / 85$ & $n=34$ \\
2. Half duration of spikes (msec) & $0.65 \pm 0.03$ & $0.3 / 1.2$ & $n=41$ \\
3. Spike threshold (mV) & $-41.4 \pm 0.7$ & $-34 /-54$ & $n=41$ \\
4. V Overshoot $(\mathrm{mV})$ & $15.4 \pm 0.9$ & $6 / 24$ & $n=34$ \\
5. V AHP (mV) & $-60.3 \pm 0.8$ & $-50 /-76$ & $n=41$ \\
6. AHP amplitude (mV) & $13.8 \pm 0.5$ & $7.5 / 20.0$ & $n=41$ \\
\hline
\end{tabular}

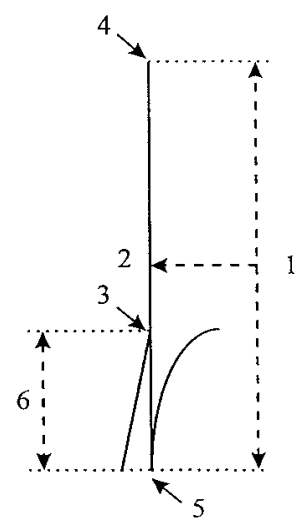

The different parameters were obtained from intracellularly recorded STN neurons. The numbers on the diagram of a single spike indicate how the different parameters were measured.

Table 2. Quantitative parameters of the burst-firing mode

A. Long bursts (pure mode)

B. Long bursts (mixed mode)

A vs B

1. Threshold (mV)

$-50.4 \pm 1.0$

$-49.1 \pm 1.2$

$(-40 /-60, n=20)$

$(-45 /-60, n=12)$

$p=0.41$

2. Duration (sec)

$1.9 \pm 0.1$

$2.1 \pm 0.2$

3. V AHP (mV)

$(0.8 / 3.0, n=22)$

$(1.0 / 3.6, n=14)$

$p=0.44$

$-61.8 \pm 0.8$

$-60.8 \pm 0.9$

$(-58.0 /-72.0, n=20)$

$(-58.0 /-70.0, n=12)$

$p=0.43$

4. AHP Amplitude (mV)

$17.7 \pm 0.7$

$18.9 \pm 0.6$

$(10.3 / 25.0, n=22)$

$(15.0 / 22.5, n=14)$

$p=0.23$

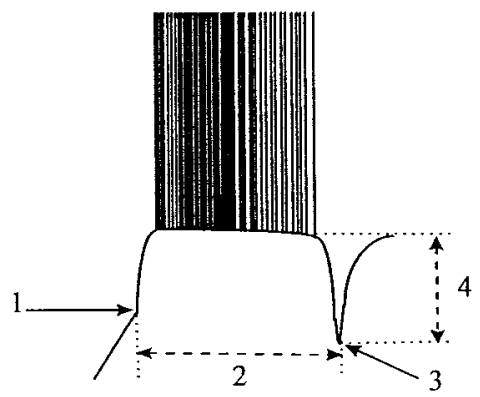

The different parameters were obtained from patch-clamp-recorded STN neurons. Parameters in column A refer to long bursts of the pure burst mode, whereas parameters in column B refer to long bursts from the mixed burst mode. Values are expressed as mean $\pm \mathrm{SEM}$; the range (minimum and maximum values) and the number of cells are indicated in parentheses.

The numbers on the diagram of a long burst indicate how the different parameters were measured.

Duvoisin, 1995) induced burst firing in some STN neurons that bursted poorly in control ( $n=16$ of 20 , data not shown).

Quantitative characteristics of the two firing modes are summarized in Tables 1 and 2. The single-spike mode was characterized by an extreme regularity and a rather high frequency $(22.3 \pm$ $1.5 \mathrm{~Hz} ; n=41$; Fig. 2). Burst-firing mode could be divided into "pure burst mode" consisting of long-lasting bursts of even dura- tion (Fig. 3A) and "mixed burst mode" alternating bursts of long and short duration (Fig. $3 B$ ). Discharge frequency of long bursts in the pure burst mode was highly variable $(15.0 \pm 1.4$ bursts/min; range, $7-29$ bursts/min; $n=21$ ). Long bursts (lasting $>800 \mathrm{msec}$ ) gave rise to numerous spikes with a "crescendo-decrescendo" frequency sequence: the first spike was followed by a rapid increase in spike frequency that reached a maximum before the end 

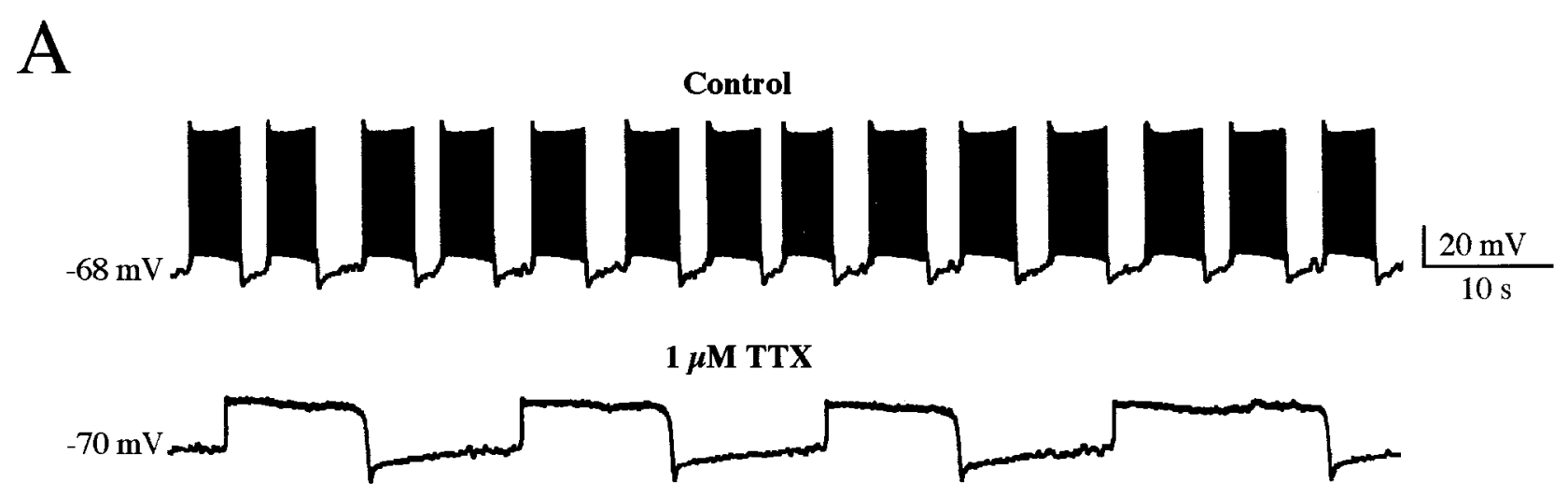

B

Control
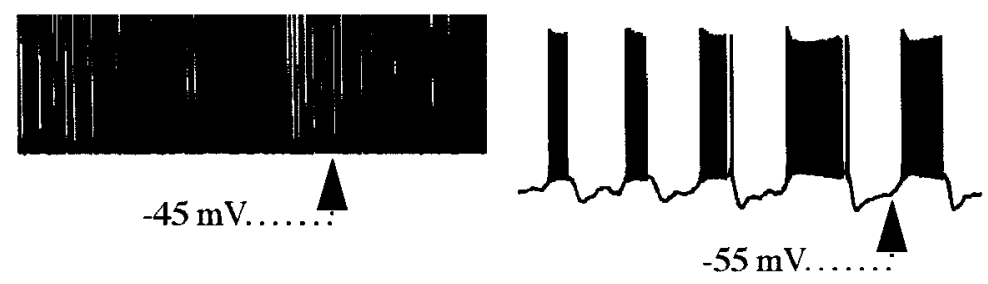

$3 \mu \mathrm{M}$ Nifedipine
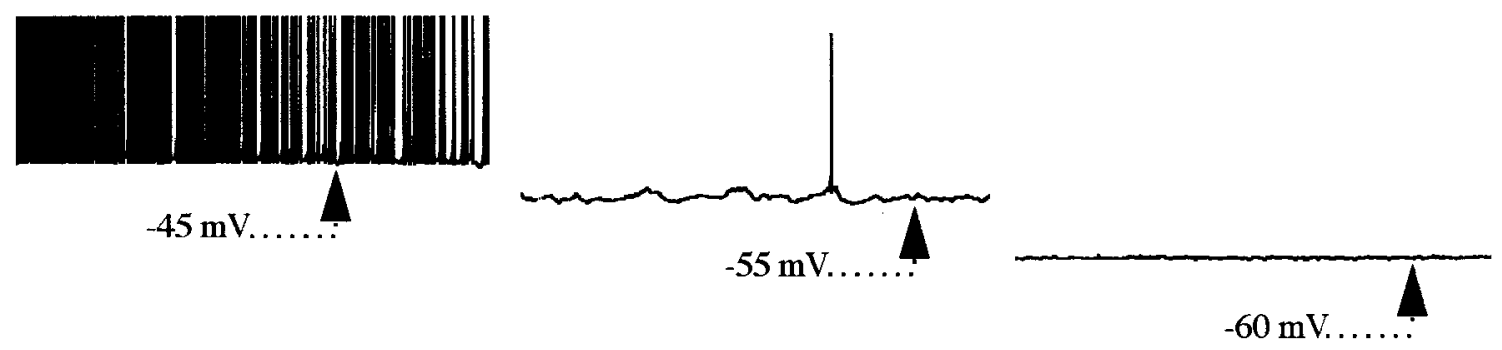

Figure 5. Ionic basis of the burst-firing mode I. $A$, TTX $(1 \mu \mathrm{M})$ totally suppressed action potentials evoked during bursts while sparing the rhythmic oscillations of the membrane potential that underlie bursts. Note the increase in the duration of membrane oscillations in the presence of TTX (from $5.0 \pm 0.0 \mathrm{sec}$ to $16.4 \pm 3.1 \mathrm{sec})$. $B$, The duration of bursts was irreversibly decreased by an application of nifedipine ( $3 \mu \mathrm{M}$, bottom trace $)$ at all tested potentials, whereas the single-spike mode was unaffected. Traces in $A$ and $B$ were obtained from two different STN neurons recorded with patch-clamp techniques in whole-cell configuration. Spikes from the single-spike mode in $B$ are truncated. Calibration is the same for traces of each section.

of the burst. Frequency then decreased as membrane potential slowly repolarized during bursts (Fig. 4, right bottom trace). Table 2 recapitulates the quantitative characteristics of the burst-firing mode. On the basis of the three parameters studied, there was no statistical difference between long bursts taken from "pure burst" or from "mixed burst" firing modes (Table 2).

Burst-firing mode was recorded using both patch-clamp and intracellular techniques. Noteworthy, spontaneous bursts were also observed in the cell-attached configuration in patch-clamp experiments (Fig. 3C). However, the relative percentage of bursting neurons varied according to the recording technique, because burst firing was more often observed in patch-clamp recordings $(48 \%)$ than in intracellular recordings $(36 \%)$. The input resistance of bursting cells was not significantly different from that of cells that did not burst $(195.2 \pm 9.4 \mathrm{M} \Omega$ and $225.2 \pm 15.0 \mathrm{M} \Omega$, respectively; $p=0.1 ; n=48$; whole-cell recordings).

\section{Ionic basis of burst-firing mode}

Pharmacological studies were performed in the whole-cell configuration. TTX $(1 \mu \mathrm{M})$ suppressed action potentials, but spared rhythmic membrane oscillations underlying bursts whose duration was increased by $358 \pm 76 \%$ as compared with control $(n=$ 5; Fig. 5A). Knowing that $\mathrm{Ca}^{2+}$-dependent mechanisms are often involved in burst generation, we tested several drugs known to interfere with $\mathrm{Ca}^{2+}$ entry or intracellular free $\mathrm{Ca}^{2+}$ ions. They all had an inhibitory effect on burst firing. Bath application of nifedipine $(3 \mu \mathrm{M})$, an L-type $\mathrm{Ca}^{2+}$ channel blocker, largely reduced the duration of bursts and even suppressed burst firing $(n=$ $9)$ at any potential tested $(n=4$; Fig. $5 B)$. This effect did not reverse throughout the experiment $(1-2 \mathrm{hr})$. Nickel $\left(\mathrm{Ni}^{2+}\right)$ at a concentration that preferentially blocks $\mathrm{T} / \mathrm{R}$-type $\mathrm{Ca}^{2+}$ channels (40 $\mu \mathrm{M}$, data not shown) (Fox et al., 1987) had a similar, but 

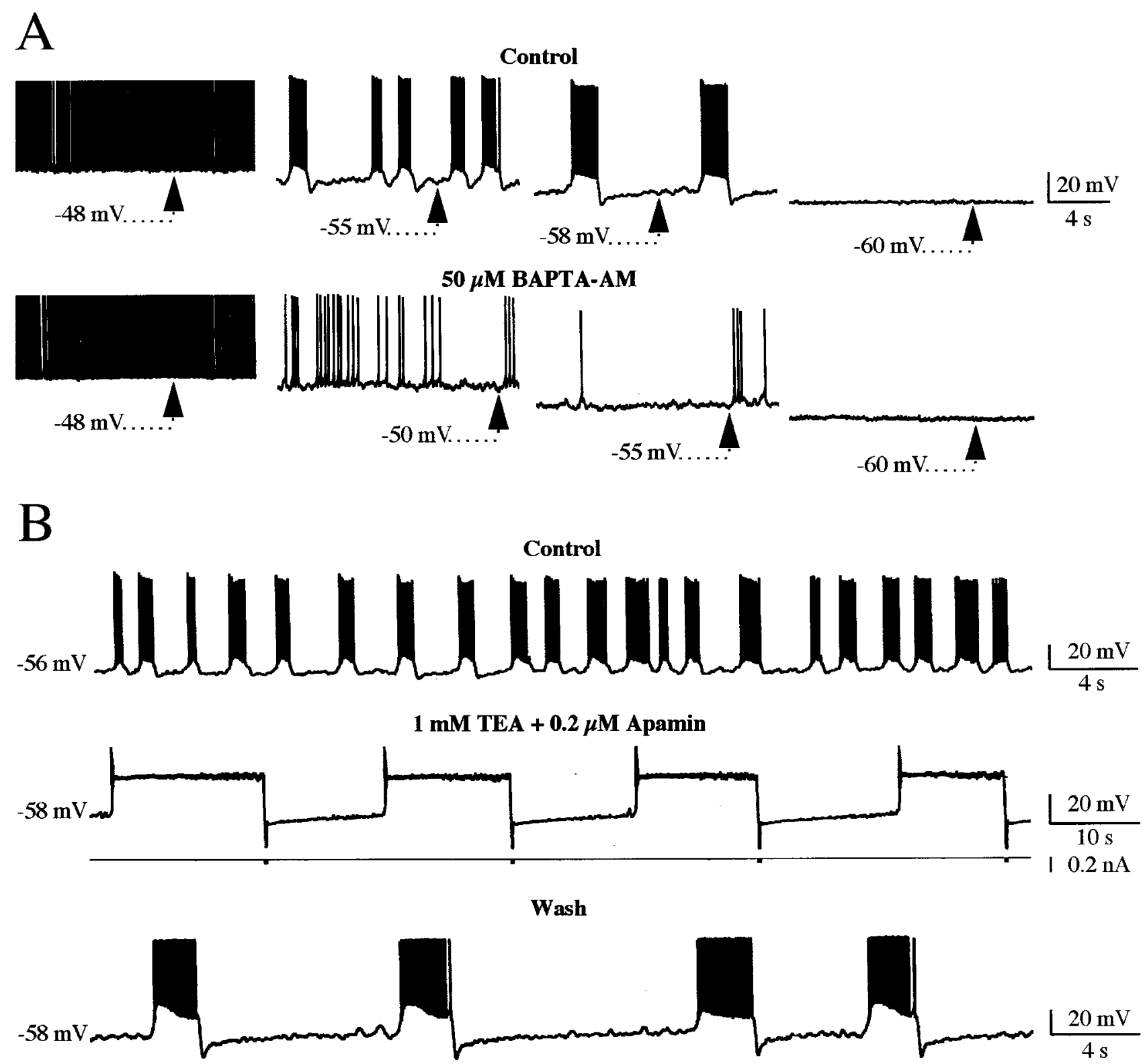

Figure 6. Ionic basis of the burst-firing mode II. $A$, Bath application of BAPTA-AM $(50 \mu \mathrm{M})$ decreased burst duration at any potential tested, although it spared the single-spike activity (left column). B. Simultaneous application of TEA (1 mM) and apamin $(0.2 \mu \mathrm{M})$ prevented burst repolarization and locked membrane potential at $-30 \mathrm{mV}$. Repolarizations were obtained by injecting brief hyperpolarizing current pulses $(-80 \mathrm{pA}, 100 \mathrm{msec})$. After each repolarizing command, the membrane spontaneously depolarized again (middle trace). As drugs washed out, bursts reappeared, but with a longer duration $(2.9 \pm 0.1 \mathrm{sec}$ vs $1.7 \pm 0.2 \mathrm{sec}$, bottom trace). Traces in $A$ and $B$ were obtained from two different STN neurons with patch-clamp recordings in whole-cell configuration. Spikes from the single-spike mode in $A$ (on the left) are truncated.

reversible effect: it decreased the duration of bursts $(n=8)$ at any potential tested $(n=3)$. Finally, bath application of the permeable form of the $\mathrm{Ca}^{2+}$ chelator BAPTA (BAPTA-AM, 10-50 $\mu \mathrm{M})$ largely reduced the duration of bursts and even suppressed burst firing after a delay of $\sim 40 \mathrm{~min}(n=7)$ at any potential tested ( $n=4$; Fig. $6 A)$.

To analyze whether $\mathrm{Ca}^{2+}$-activated $\mathrm{K}^{+}$currents play a role in burst repolarization, tetraethylammonium (TEA; $1 \mathrm{~mm}$ ) was applied at a concentration that blocks the big conductance $\mathrm{Ca}^{2+}$ dependent $\mathrm{K}^{+}$current, but not the delayed rectifier one. The TEA was applied in combination with apamin $(0.2 \mu \mathrm{M})$, the selective blocker of the small conductance $\mathrm{Ca}^{2+}$-dependent $\mathrm{K}^{+}$ current (for review, see Sah, 1996). TEA and apamin totally prevented burst repolarization and suppressed spikes, except a few early ones (Fig. $6 B ; n=4$ ). The sustained depolarization of the membrane, resulting from the blockade of $\mathrm{Ca}^{2+}$-activated $\mathrm{K}^{+}$currents suppressed spikes, probably by inactivating $\mathrm{Na}^{+}$channels as already described in cortical neurons (Prince and Connors, 1986). Short hyperpolarizing current pulses (100 msec, $-80 \mathrm{pA}$ ) were needed to cut off bursts (Fig. 6B, middle traces). As the drugs washed out, bursts spontaneously repolarized, although after a longer duration than in control, and spikes reappeared (Fig. 6B, bottom trace).

To better understand the $\mathrm{Ca}^{2+}$ and $\mathrm{Ca}^{2+}$-activated currents present in STN neurons, their responses to current pulses were then analyzed. 

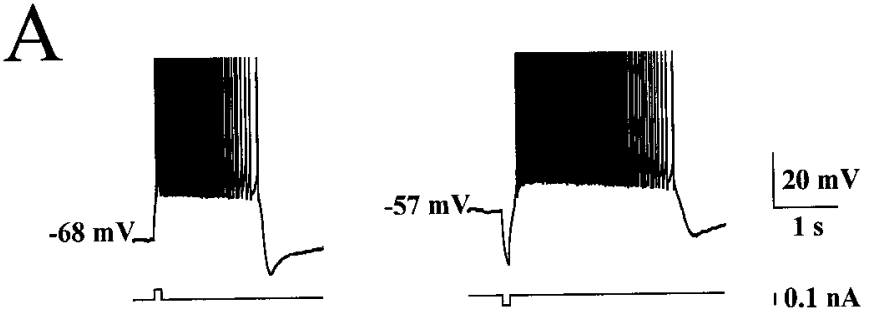

B

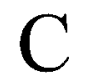

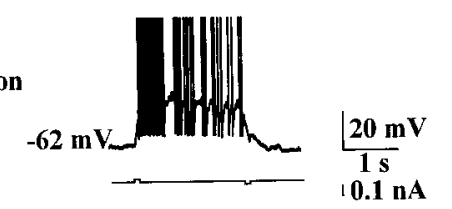

$0.1 \mathrm{nA}$

$\mathrm{D}$

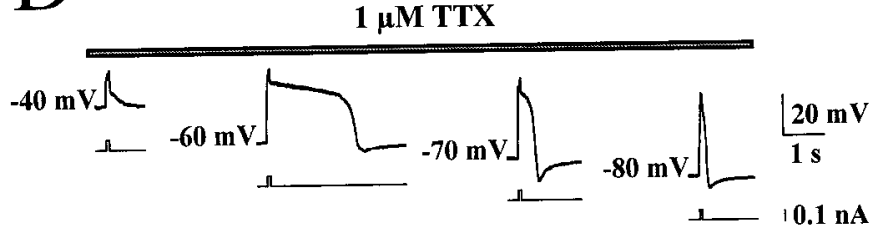

Figure 7. Plateau potentials. A, A short depolarizing (100 pA, $100 \mathrm{msec}$, left trace) or hyperpolarizing $(-100 \mathrm{pA}, 100 \mathrm{msec}$, right trace) current pulse triggered both a plateau potential $(1.8$ and $2.6 \mathrm{msec}$ duration, respectively) that considerably outlasted the duration of the stimulus and was followed by a prominent AHP (28 and $17 \mathrm{mV}$ amplitude, respectively). $B$, TTX $(1 \mu \mathrm{M})$ revealed the presence of two different phases in the plateau potential: a slow depolarization triggered by the depolarizing current pulse $(50 \mathrm{pA}, 200 \mathrm{msec})$ and an afterdepolarization $(267 \mathrm{msec})$ triggered at the break of the current pulse. $C$, Long duration plateau potential terminated by a short hyperpolarizing current pulse $(-20 \mathrm{pA}$, $100 \mathrm{msec}$ ). $D$, Amplitude and duration of the plateau potential according to membrane potential. In the presence of TTX $(1 \mu \mathrm{M})$, the same depolarizing current pulse $(100 \mathrm{pA}, 100 \mathrm{msec})$ evoked a plateau potential in the membrane potential range of -60 to $-70 \mathrm{mV}$. At more depolarized $(-40 \mathrm{mV}$, extreme left $)$ or hyperpolarized $(-80 \mathrm{mV}$, extreme right $)$ potentials, the amplitude and duration of the plateau potential was considerably reduced. Traces in $A, C$, and $D$ were obtained with patch-clamp recordings (whole-cell configuration), and traces in $B$ were obtained with intracellular recordings. All spikes are truncated.

Ionic basis of responses to intracellular current pulses

Injection of depolarizing or hyperpolarizing current pulses in STN neurons triggered two kinds of responses: a long depolarization that outlasted the current pulse (Figs. 7, 8, plateau potentials) and/or a short depolarizing rebound [low-threshold spike (LTS); Fig. 9].

\section{The plateau potential}

Plateau potentials, as burst-firing mode, were more often observed in whole-cell patch-clamp recordings than in intracellular recordings (93 vs $62 \%$, respectively). In response to depolarizing or hyperpolarizing current pulses (100 pA, $100 \mathrm{msec}), 86$ STN neurons of the 106 tested $(82 \%)$ generated long-lasting plateau potentials (mean duration, $1043.7 \pm 69.8 \mathrm{msec}$; range, 300-2500 msec; $n=52$ ) that gave rise to numerous action potentials (Fig. $7 A$ ). Plateau potential duration was measured from the beginning of the current pulse to the peak of the AHP. During plateaus, spike frequency increased until the end of the depolarizing current pulse and then gradually decreased during the rest of the
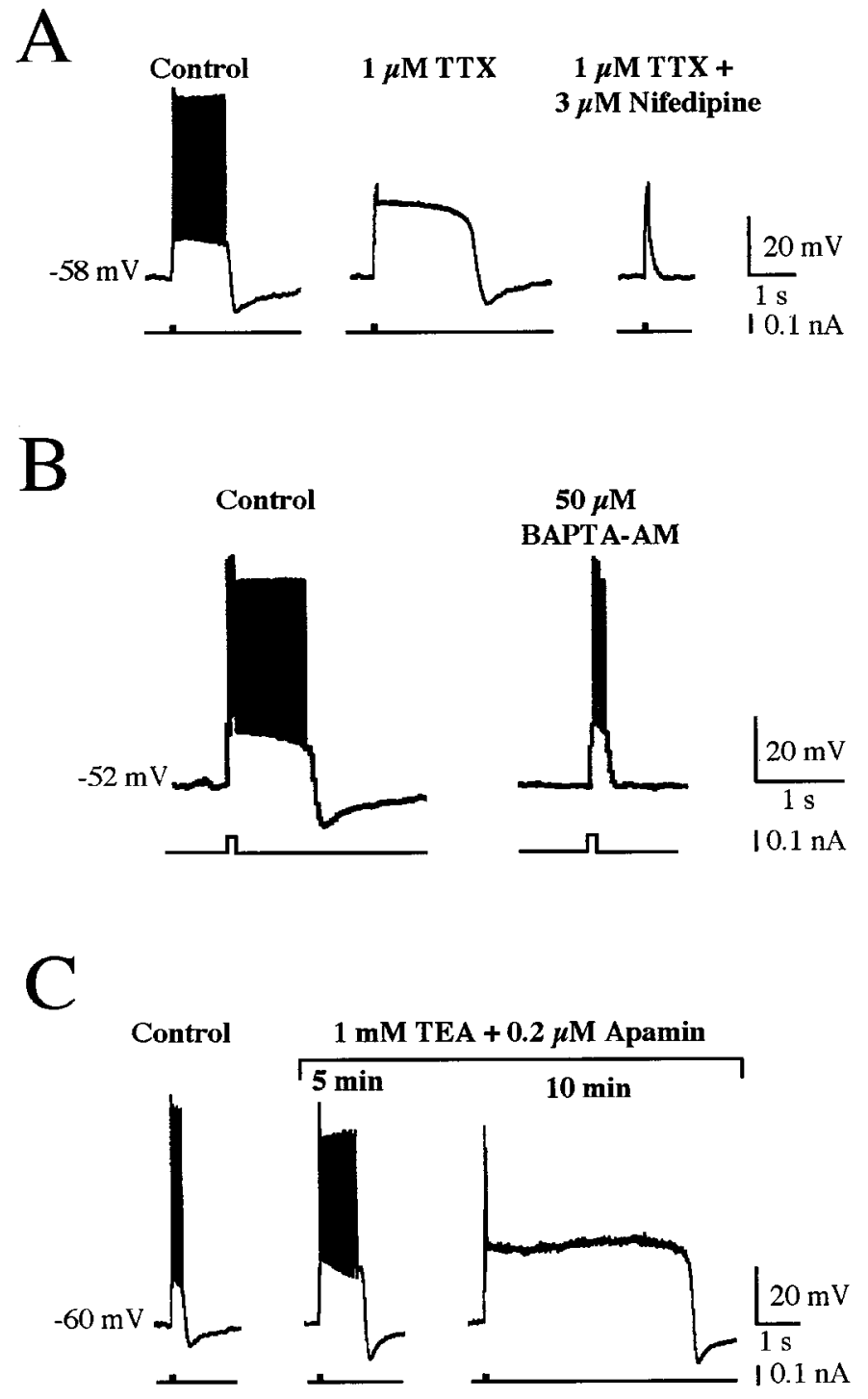

Figure 8. Ionic basis of the plateau response. $A$, TTX $(1 \mu \mathrm{M})$ suppressed action potentials but not the plateau potential (middle trace) evoked by a $100 \mathrm{pA}, 100 \mathrm{msec}$ current pulse (left trace). In the presence of TTX, bath application of nifedipine $(3 \mu \mathrm{M})$ suppressed the plateau potential (right trace). $B$, The duration of the plateau potential was also decreased by bath application of BAPTA-AM $(50 \mu \mathrm{M})$. Note that the cell fired some action potentials during the current pulse $(100 \mathrm{pA}, 100 \mathrm{msec}) . C$, In contrast, the plateau potential was significantly increased by simultaneous application of TEA ( $1 \mathrm{mM})$ and apamin $(0.2 \mu \mathrm{M})$ from $0.5 \mathrm{sec}$ (left trace) to $5.5 \mathrm{sec}$ (right trace). All traces were obtained with patch-clamp recordings (whole-cell configuration).

plateau phase, thus showing some adaptation (Fig. 7A). Two different phases were easily identified in the presence of TTX (1 $\mu \mathrm{M})$ : a ramp-like, slow-rising depolarization that corresponded to the duration of the depolarizing current pulse, and an afterdepolarization that outlasted the current pulse (Fig. 7B). Plateau potentials spontaneously ended with an AHP of $20.6 \pm 0.8 \mathrm{mV}$ amplitude (range, $10-35 \mathrm{mV} ; n=52$ ) and could also be terminated by a short hyperpolarizing current pulse (Fig. 7C). AHP amplitude was measured in the same way as in burst-firing mode (Table 2). Plateau potentials were triggered within a narrow range of membrane potentials, between -50 and $-75 \mathrm{mV}(n=$ 43; Fig. $7 D$ ), thus showing that they resulted from the activation of voltage-dependent conductances. 

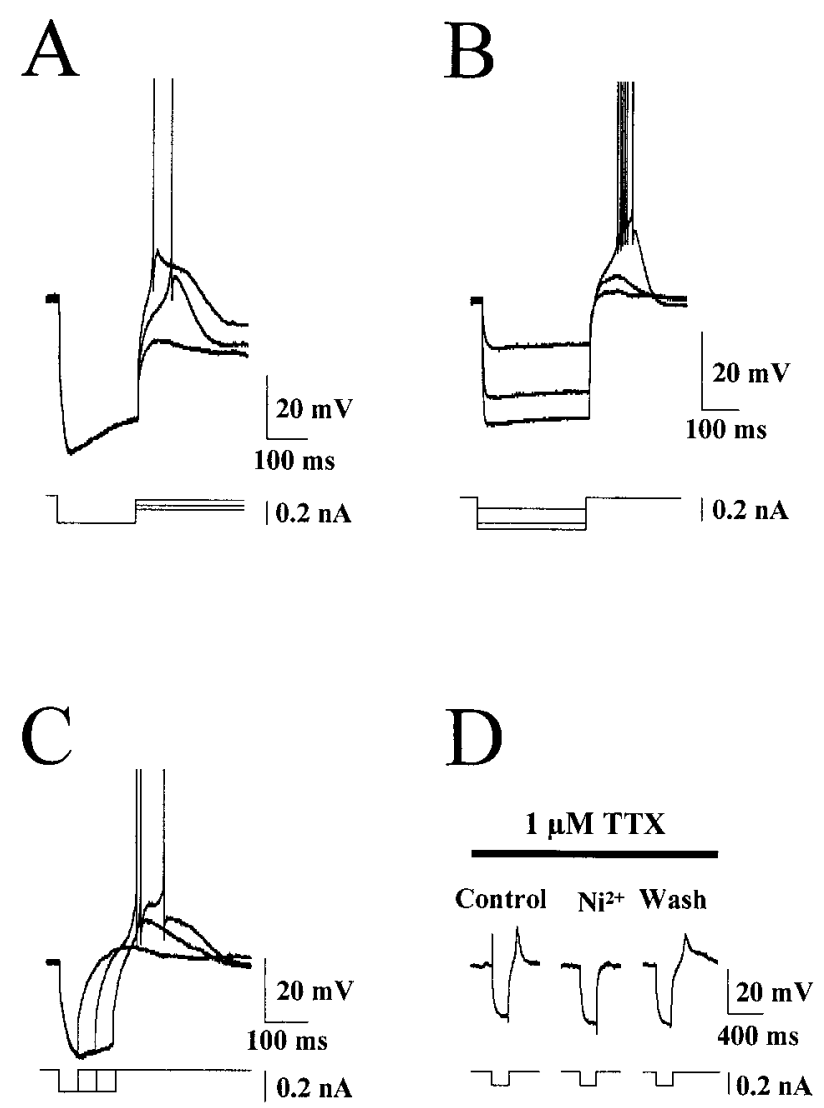

Figure 9. Voltage dependency and pharmacological properties of LTS. $A$, The three superimposed voltage traces show that LTS was recorded at the break of a hyperpolarizing current pulse $(-300 \mathrm{pA}, 200 \mathrm{msec})$ applied at a membrane potential of $-63 \mathrm{mV}$. Its amplitude and rise time depended on the value of membrane potential at the end of the negative current pulse: at $-78 \mathrm{mV}$, LTS was not evoked (bottom trace), whereas at a slightly more depolarized potential (approximately $-72 \mathrm{mV}$, middle trace) it was present and gave rise to a spike. With increased depolarization, LTS amplitude increased, and spike delay decreased (top trace). B, Three superimposed responses to hyperpolarizing current pulses of increasing amplitude $(-100,-250$, and $-350 \mathrm{pA})$ and fixed duration (300 $\mathrm{msec}$ ) from $\mathrm{Vm}=-53 \mathrm{mV}$. LTS was only evoked when the membrane was held for $300 \mathrm{msec}$ at a potential more hyperpolarized than $-78 \mathrm{mV}$ for $300 \mathrm{msec}$. $C$, Three superimposed voltage traces in response to hyperpolarizing current pulses of fixed amplitude $(-150 \mathrm{pA})$ and increasing duration $(40,80$, and $120 \mathrm{msec})$. LTS was evoked in a neuron maintained at $-64 \mathrm{mV}$ when the membrane was held at $-85 \mathrm{mV}$ for at least $80 \mathrm{msec}$ during the application of a hyperpolarizing current pulse. $D$, In the presence of TTX $(1 \mu \mathrm{M})$, LTS evoked in response to a hyperpolarizing current pulse $(-130 \mathrm{pA}, 200 \mathrm{msec})$ from $\mathrm{Vm}=-70 \mathrm{mV}$ was not affected (Control and Wash), whereas it was reversibly suppressed by the concomitant application of $\mathrm{Ni}^{2+}(40 \mu \mathrm{M})$. Traces in $A, C$, and $D$ were obtained with intracellular recordings, and traces in $B$ were obtained with patch-clamp recordings (whole-cell configuration). All spikes are truncated.

Ionic currents underlying plateau potentials were analyzed in whole-cell recordings with the use of channel blockers. TTX (1 $\mu \mathrm{M}$ ) suppressed $\mathrm{Na}^{+}$-dependent spikes ( $n=19$ of 19) (Fig. 8A, middle trace) but did not affect the plateau response. A low $\mathrm{Ca}^{2+}$ $(0.4 \mathrm{~mm})$ extracellular solution containing $\mathrm{Co}^{2+}(2 \mathrm{mM}) \mathrm{com}-$ pletely suppressed plateau potentials ( $n=5$, data not shown). To determine the type of voltage-gated $\mathrm{Ca}^{2+}$ currents involved, $\mathrm{Ca}^{2+}$ channel blockers were tested. Nifedipine $(3 \mu \mathrm{M})$ suppressed plateau potentials $(n=8$; Fig. $8 A)$, whereas $\mathrm{Ni}^{2+}(40 \mu \mathrm{M})$ had no effect $\left(n=5\right.$; data not shown). Chelation of intracellular $\mathrm{Ca}^{2+}$ with either BAPTA-AM (10-50 $\mu \mathrm{M} ; n=4$; Fig. $8 B)$ or BAPTA in the pipette solution ( $20 \mathrm{mM} ; n=2$; data not shown) suppressed or decreased the plateau potential duration after $\sim 30$ and $20 \mathrm{~min}$, respectively. These results suggest that both $\mathrm{Ca}^{2+}$ entry through L-type $\mathrm{Ca}^{2+}$ channels and intracellular free $\mathrm{Ca}^{2+}$ ions are involved in the generation of plateau potentials. Simultaneous application of TEA $(1 \mathrm{mM})$ and apamin $(0.2 \mu \mathrm{M})$ increased the duration of plateau potentials by $610 \pm 297 \%(n=7$; Fig. $8 C)$. In some cells $(n=2)$, spikes were suppressed probably as a result of the sustained membrane depolarization and the consequent $\mathrm{Na}^{+}$channels inactivation. Similarly, $1 S, 3 R$-ACPD $(25 \mu \mathrm{M})$ increased plateau potential duration by $252 \pm 37 \%(n=10$; data not shown).

\section{The low-threshold spike}

A small, transient depolarization triggering a few spikes was observed at the break of a short hyperpolarizing current pulse in $71 \%$ of the STN neurons tested ( $n=66$ of 93; Fig. 9). In the remaining $29 \%(n=27)$, the small depolarizing rebound was masked by a plateau potential response. This postinhibitory rebound, previously described in STN neurons (Nakanishi et al., 1987; Overton et al., 1995) and in other preparations (for review, see Huguenard, 1996), has been called an LTS, because of its negative threshold compared with that of $\mathrm{Na}^{+}$-dependent spikes. As illustrated in Figure 9 $A$, LTS amplitude increased with membrane depolarization at the end of the pulse. It is worthwhile noting the depolarizing sag of the membrane potential, a typical sign of the presence of the hyperpolarization-activated cation current $\left(I_{\mathrm{h}}\right)$ previously described in STN neurons (Nakanishi et al., 1987; Overton et al., 1995). Currents underlying LTS inactivated with depolarization as LTS was triggered, but only after maintaining the membrane at potentials more hyperpolarized than $-84 \mathrm{mV}$ for $300-400 \mathrm{msec}(n=9$; Fig. $9 B)$. LTS inactivation was also time-dependent, as illustrated in Figure $9 C$, in which membrane potential had to be maintained at $-85 \mathrm{mV}$ for at least $80 \mathrm{msec}$ to trigger an LTS. LTS was unaffected by TTX $(1 \mu \mathrm{M}$; $n=6$; Fig. 9D) but completely disappeared in a $\mathrm{Ca}^{2+}$-free $\mathrm{Co}^{2+}$-containing $(2.4 \mathrm{~mm})$ external solution $(n=3$; data not shown), or in the presence of a low concentration of $\mathrm{Ni}^{2+}(40 \mu \mathrm{M}$; $n=5$; Fig. 9D). All these results suggest that a rapid voltageinactivating, $\mathrm{Ni}^{2+}$-sensitive current such as the low-threshold T/R-type $\mathrm{Ca}^{2+}$ current underlies LTS.

\section{DISCUSSION}

The main result of our study is that approximately half of the STN neurons in the slices have the intrinsic property of switching from single-spike activity to burst-firing mode. To the best of our knowledge, this type of functional property is unknown in neurons of the various basal ganglia nuclei. It may emphasize the role of STN neurons in normal and parkinsonian states.

\section{The cascade of currents underlying burst-firing mode}

In tonic and bursting modes, STN neurons fire $\mathrm{Na}^{+}$-dependent action potentials. In burst-firing mode, neurons display cycles of membrane oscillations (Fig. 10,b-a) separated by slow membrane depolarizations (Fig. 10,a-b). We have shown that the three phases of bursts: depolarization $(b-c)$, slowly declining plateau $(c-d)$, and repolarization to the AHP $(d-a)$, are dependent on $\mathrm{Ca}^{2+}$ entry through voltage-sensitive $\mathrm{Ca}^{2+}$ channels. We propose that the depolarization phase $(b-c)$ results from a lowthreshold T/R-type $\mathrm{Ca}^{2+}$ current $\left(I_{\mathrm{T} / \mathrm{R}}\right)$ that depolarizes the membrane to the threshold potential of the nifedipine-sensitive L-type $\mathrm{Ca}^{2+}$ current $\left(I_{\mathrm{L}}\right)$ and then inactivates. The slowly inac- 


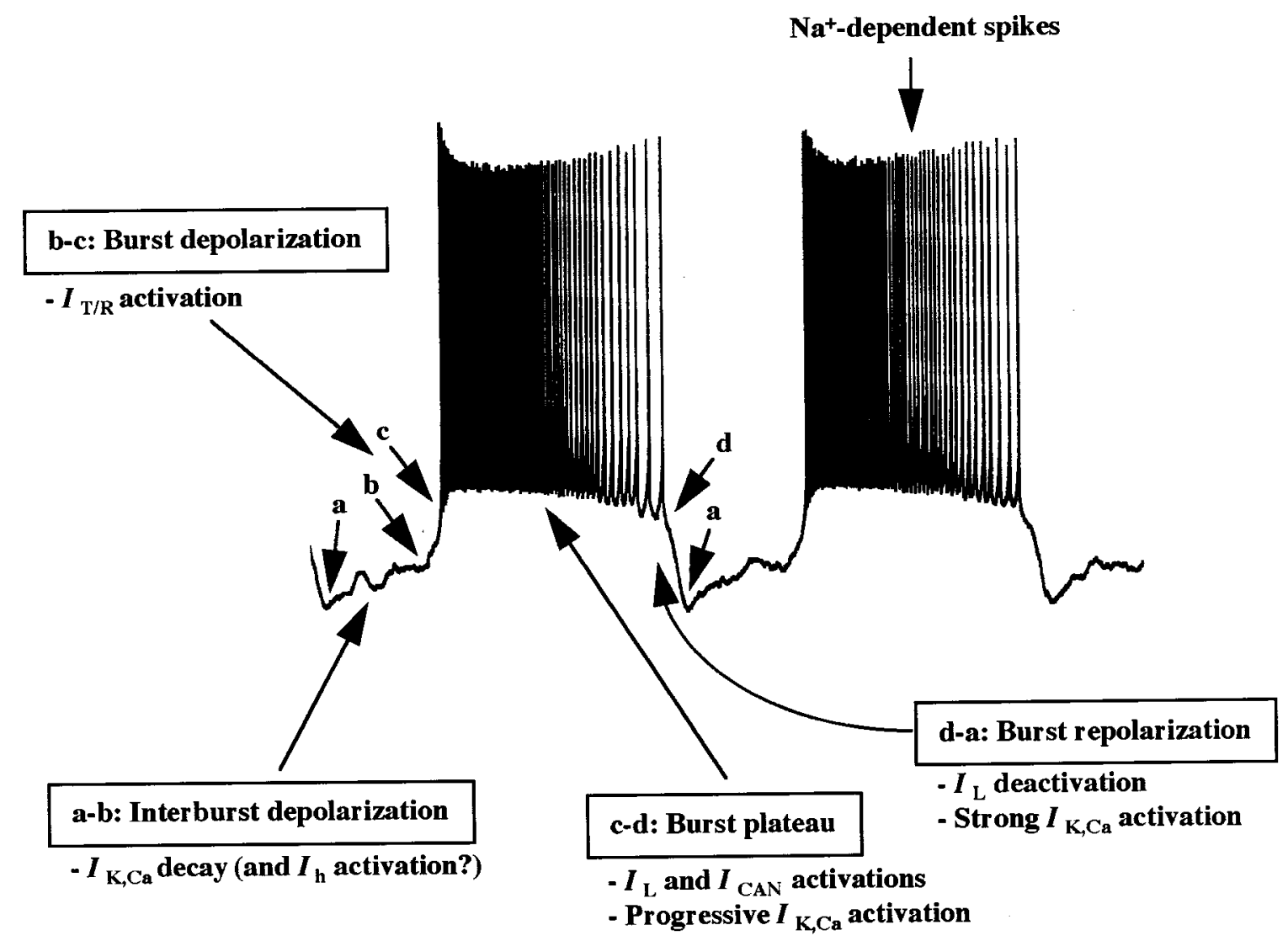

Figure 10. The hypothetical cascade of currents underlying the different phases of burst-firing mode. See Discussion for explanation.

tivating $I_{\mathrm{L}}$ depolarizes the membrane to the plateau phase of bursts during which spikes are evoked $(c-d)$. Spikes amplify $\mathrm{Ca}^{2+}$ entry by activating more $I_{\mathrm{L}}$ and, possibly, other types of highthreshold $\mathrm{Ca}^{2+}$ currents (Song et al., 1997). The resulting increase in intracellular $\mathrm{Ca}^{2+}$ concentration activates the TEAand apamin-sensitive $\mathrm{Ca}^{2+}$-activated $\mathrm{K}^{+}$currents $\left(I_{\mathrm{K}, \mathrm{Ca}}\right)$. The balance between depolarizing $\left(I_{\mathrm{L}}\right)$ and hyperpolarizing $\left(I_{\mathrm{K}, \mathrm{Ca}}\right)$ currents, slightly in favor of the latter, explains the gradual decline of the plateau (decrescendo phase). When membrane potential has declined to a certain level, it suddenly repolarizes $(d-a)$ because of rapid $I_{\mathrm{L}}$ deactivation (Reuveni et al., 1993) and stronger $I_{\mathrm{K}, \mathrm{Ca}}$ activation. This leads to the peak of AHP, during which $I_{\mathrm{T} / \mathrm{R}}$ deinactivates. The membrane then spontaneously depolarizes $(a-b)$ as $I_{\mathrm{K}, \mathrm{Ca}}$ decays because of $\mathrm{Ca}^{2+}$ clearance mechanisms. Depolarization to the threshold potential of $I_{\mathrm{T} / \mathrm{R}}$ initiates a new cycle. Because BAPTA suppressed burst firing, instead of blocking burst repolarization by preventing $I_{\mathrm{K}, \mathrm{Ca}}$ activation, this suggests the participation of a $\mathrm{Ca}^{2+}$-dependent inward current, such as the nonspecific cationic current $\left(I_{\mathrm{CAN}}\right)$ in the plateau phase of bursts $(c-d)$. The progressive activation of this inward current (together with high voltage-activated $\mathrm{Ca}^{2+}$ currents) may underlie spike acceleration (crescendo phase) during burst and plateau potential as previously described for bursts of rat thalamic reticular neurons (Huguenard and Prince, 1992). Finally, $I_{\mathrm{h}}(\mathrm{Na}-$ kanishi et al., 1987; Overton et al., 1995; present study) recorded in some STN neurons (Fig. 9A) may also participate in the slow depolarization between consecutive bursts.

Burst-firing mode was observed in whole-cell recordings as well as in recording configurations in which the intracellular medium was left intact, such as cell-attached or intracellular recordings.
These results showed that burst firing is a physiological firing mode of STN cells. This mode was, however, more easily obtained when $\mathrm{K}^{+}$currents were decreased because of the presence of gluconate in the pipette solution (Velumian et al., 1997), or when I-IImGluRs were activated with $1 S, 3 R$-ACPD (Nakanishi, 1994; Pin and Duvoisin, 1995). The activation of $I_{\mathrm{L}}$ (Chavis et al., 1995; Russo et al., 1997; Svirskis and Hounsgaard, 1998) or $I_{\text {CAN }}$ (Crépel et al., 1994; Guérineau et al., 1995; Congar et al., 1997), and/or the inhibition of $\mathrm{K}^{+}$currents (Charpak et al., 1990; Guérineau et al., 1994; Schrader and Tasker, 1997) by the stimulation of mGluRs may account for the triggering of burst firing by $1 S, 3 R$-ACPD. Indeed, the presence of mGluRs (subtypes 2, 3, and 1a) has been reported in the STN neuropile (Martin et al., 1992; Testa et al., 1998) as well as that of mGluR2 mRNA in STN neurons (Testa et al., 1994).

\section{The presence of a plateau potential response is a characteristic of bursting STN neurons}

We have shown in the present study that the ionic conductances underlying bursts and plateau potentials are the same: (1) bursts and plateau potentials shared the same pharmacological sensitivity; (2) the same promoting effect of intracellular gluconate and $1 S, 3 R$-ACPD was observed in the occurence of bursts and plateau potentials, and (3) only cells exhibiting a plateau potential were able to generate bursts, either spontaneously or in response to $1 S, 3 R$-ACPD, and the reverse also holds true: STN neurons in which plateau potentials could not be triggered were not able to burst. However, this was not the only prerequisite for bursting, because $76 \%$ of cells responding with a plateau potential never bursted. The only difference is the lack of effect of a low concen- 
tration of extracellular $\mathrm{Ni}^{2+}$ on plateau potentials. This can be explained by the fact that the depolarizing current pulse applied to trigger the plateau potential replaced the $\mathrm{Ni}^{2+}$-sensitive $\mathrm{T} / \mathrm{R}$ type $\mathrm{Ca}^{2+}$ current that normally supported the slow depolarization between bursts. The other type of triggered response, LTS, was present in all recorded STN neurons. Therefore, we propose to distinguish between two populations of STN neurons in vitro, those that are able to burst and generate LTS and plateau potentials and those that are not able to burst and only respond with an LTS. We propose that the difference between these two populations is the presence of the inward currents that underlie the plateau phase of bursts or the plateau potentials i.e., mainly $I_{\mathrm{L}}$ and $I_{\mathrm{CAN}}$.

Single-spike modes with frequencies comparable to the ones reported in the present study (Nakanishi et al., 1987; Overton et al., 1995) have already been described in STN neurons in acute slices. To our knowledge, burst-firing mode had only once been recorded in vitro, (in organotypic cultures of STN neurons with intracellular recording techniques), but their ionic mechanisms were not analyzed (Plenz et al., 1997). In contrast, evoked responses similar to the ones reported here have been previously described. The "slow depolarizing potentials" mentioned by Nakanishi et al. (1987) are similar to the plateau potentials we described, which were triggered when the membrane potential was in the -50 to $-60 \mathrm{mV}$ range. Likewise, the "slow action potentials" (Nakanishi et al., 1987), "strong rebound bursts" (Plenz et al., 1997), and the "LTS" (Overton et al., 1995) correspond to the LTS described in the present study. Because these different studies did not include precise pharmacological characterization, this similarity is based only on the voltage dependence of the responses. In vivo, both tonic and bursting activities have been recorded in rat and monkey STN (Hollerman and Grace, 1992; Fujimoto and Kita, 1993; Bergman et al., 1994; Overton and Greenfield, 1995; Kreiss et al., 1997). However, the switch from one mode to the other, and the ionic mechanisms of the bursting mode, have not been observed or analyzed in either of the preparations.

\section{Functional implications}

In a normal in vivo situation, the great majority of rat and monkey STN neurons present a tonic activity with a frequency varying from 5 to $65 \mathrm{~Hz}$, and few neurons discharge in bursts (Matsumara et al., 1992; Wichmann et al., 1994; Overton and Greenfield, 1995). In relation with conditioned arm (Georgopoulos et al., 1983; Miller and DeLong, 1987; Wichmann et al., 1994) or saccadic eye (Matsumara et al., 1992) movements, a burst of highfrequency spikes lasting $\sim 200-300 \mathrm{msec}$ is usually recorded after the onset of the movement. Because we showed in the present study that bursts or plateau potentials are triggered by membrane hyperpolarization, the movement-correlated burst of action potentials may result from the activation of inhibitory afferents to the STN.

The increase in the percentage of bursts in the discharge of STN neurons is noteworthy after a lesion of the substantia nigra pars compacta in rats and monkeys in vivo (Hollerman and Grace, 1992; Bergman et al., 1994; Hassani et al., 1996) and in parkinsonian patients (Benazzouz et al., 1996; Rodriguez et al., 1997). The origin of this modification in STN activity in a pathological situation is still under debate (for review, see Chesselet and Delfs 1996; Levy et al., 1997), although a disinhibition mechanism and increased activity of glutamatergic STN afferents seem to be crucial, according to DeLong's (1990) model. We have in fact shown that the activation of metabotropic glutamate receptors that may occur because of increased activity of glutamatergic STN afferents, strongly favored the bursting mode, as also observed in the hippocampus (Bianchi and Wong, 1995). Bursting STN neurons may drive target neurons in the internal segment of the pallidum and in substantia nigra pars reticulata, where an oscillatory activity or an increase in cytochrome oxidase activity, a marker of metabolic activity, have been recorded in animal Parkinson models (Miller and DeLong, 1987; Filion et al., 1988; Bergman et al., 1994; Nini et al., 1995; Vila et al., 1997; Bergman et al., 1998) and in parkinsonian patients (Hutchison et al., 1997; Vila et al., 1997). This suggests that the strong regulation exerted on STN neurons in control animals is disorganized in animal models of parkinsonism. This may indeed account for the switch from a tonic to a bursting mode.

\section{REFERENCES}

Albin RL, Young AB, Penney JB (1989) The functional anatomy of the basal ganglia disorders. Trends Neurosci 12:366-375.

Aziz TZ, Peggs D, Sambrook MA, Crossman AR (1991) Lesion of the subthalamic nucleus for the alleviation of 1-methyl-4-phenyl-1,2,3-6tetrahydropyridine (MPTP)-induced parkinsonism in the primate. Mov Disord 6:288-292.

Bathia KP, Marsden CD (1994) The behavioral and motor consequences of focal lesions of the basal ganglia in man. Brain 117:859-876.

Benazzouz A, Gross Ch, Féger J, Boraud Th, Bioulac B (1993) Reversal of rigidity and improvement in motor performance by subthalamic high-frequency stimulation in MPTP-treated monkeys. Eur J Neurosci 5:382-389.

Benazzouz A, Piallat B, Pollak P, Limousin P, Gao DM, Krack P, Benabid AL (1996) Single unit recordings of subthalamic nucleus and pars reticulata of substantia nigra in akineto-rigid parkinsonian patients. Soc Neurosci Abstr 22:91.18.

Bergman H, Wichmann T, DeLong MR (1990) Reversal of experimental parkinsonism by lesions of the subthalamic nucleus. Science 249:1346-1348.

Bergman H, Wichmann T, Karmon B, DeLong MR (1994) The primate subthalamic nucleus II. Neuronal activity in the MPTP model of Parkinsonism. J Neurophysiol 72:507-520.

Bergman H, Feingold A, Nini A, Raz A, Slovin H, Abeles M, Vaadia E (1998) Physiological aspects of information processing in the basal ganglia of normal and parkinsonian primates. Trends Neurosci 21:32-38.

Beurrier C, Bezard E, Bioulac B, Gross C (1997) Subthalamic stimulation elicits hemiballismus in normal monkey. NeuroReport 8:1625-1629.

Bianchi R, Wong RKS (1995) Excitatory synaptic potentials dependent on metabotropic glutamate receptor activation in guinea-pig hippocampal pyramidal cells. J Physiol (Lond) 487:663-676.

Brotchie JM, Mitchell IJ, Sambrook MA, Crossman AR (1991) Alleviation of parkinsonism by antagonism of excitatory amino acid transmission in the medial segment of the globus pallidus in rat and primate. Mov Disord 6:133-138.

Charpak S, Gähwiler BH, Do KQ, Knöpfel T (1990) Potassium conductances in hippocampal neurons blocked by excitatory amino-acid transmitters. Nature 347:765-767.

Chavis P, Nooney JM, Bockaert J, Fagni L, Feltz A, Bossu JL (1995) Facilitatory coupling between a glutamate metabotropic receptor and dihydropyridine-sensitive calcium channels in cultured cerebellar granule cells. J Neurosci 15:135-143.

Chesselet MF, Delfs JM (1996) Basal ganglia and movement disorders: an update. Trends Neurosci 19:417-422.

Congar P, Leinekugel X, Ben-Ari Y, Crépel V (1997) A long-lasting calcium-activated nonselective cationic current is generated by synaptic stimulation or exogenous activation of group I metabotropic glutamate receptors in CA1 pyramidal neurons. J Neurosci 17:5366-5379.

Crépel V, Aniksztejn L, Ben-Ari Y, Hammond C (1994) Glutamate metabotropic receptors increase a $\mathrm{Ca}^{2+}$-activated nonspecific cationic current in CA1 hippocampal neurons. J Neurophysiol 72:1561-1569.

Crossman AR, Sambrook MA, Jackson A (1984) Experimental hemichorea/hemiballismus in the monkey. Studies of the intracerebral site of action in a drug induced dyskinesia. Brain 107:579-596. 
DeLong MR (1990) Primate models of movement disorders of basal ganglia origin. Trends Neurosci 13:281-285.

Féger J, Hassani OK, Mouroux M (1997) The subthalamic nucleus and its connections. New electrophysiological and pharmacological data. Adv Neurol 74:31-43.

Filion M, Tremblay L, Bédard PJ (1988) Abnormal influences of passive limb movement on the activity of globus pallidus neurons in parkinsonian monkeys. Brain Res 444:165-176.

Fox AP, Nowycky MC, Tsien RW (1987) Kinetic and pharmacological properties distinguishing three types of calcium currents in chick sensory neurones. J Physiol (Lond) 394:149-172.

Fujimoto K, Kita H (1993) Response characteristics of subthalamic neurons to the stimulation of the sensorimotor cortex in the rat. Brain Res 609:185-192.

Georgopoulos AP, DeLong MR, Crutcher MD (1983) Relations between parameters of step-tracking movements and single cell discharge in the globus pallidus and subthalamic nucleus of the behaving monkey. J Neurosci 3:1586-1598.

Graham WC, Robertson RG, Sambrook MA, Crossman AR (1990) Injection of excitatory amino acid antagonists into the pallidal segment of the MPTP-treated primate reverses motor symptoms of parkinsonism. Life Sci 47:91-97.

Guérineau NC, Gähwiler BH, Gerber U (1994) Reduction of resting K+ current by metabotropic glutamate and muscarinic receptors in rat $\mathrm{CA} 3$ cells: mediation by G-proteins. J Physiol (Lond) 474:27-33.

Guérineau NC, Bossu JL, Gähwiler BH, Gerber U (1995) Activation of a nonselective cationic conductance by metabotropic glutamatergic and muscarinic agonists in CA3 pyramidal neurons of the rat hippocampus. J Neurosci 15:4395-4407.

Guridi J, Herrero MT, Luquin MR, Guillén J, Ruberg M, Laguna J, Vila M, Javoy-Agid F, Agid Y, Hirsch E, Obeso A (1996) Subthalamotomy in parkinsonian monkeys. Behavioural and biochemical analysis. Brain 119:1717-1727.

Hamada I, DeLong MR (1992) Excitotoxic acid lesions of the primate subthalamic nucleus result in transient dyskinesias of the contralateral limbs. J Neurophysiol 68:1850-1858.

Hammond C, Féger J, Bioulac B, Souteyrand JP (1979) Experimental hemiballism in the monkey produced by unilateral kainic acid lesion in corpus Luysii. Brain Res 171:577-580.

Hassani OK, Mouroux M, Féger J (1996) Increased subthalamic neuronal activity after nigral dopaminergic lesion independent of disinhibition via the globus pallidus. Neuroscience 72:105-115.

Hollerman JR, Grace AA (1992) Subthalamic nucleus cell firing in the 6-OHDA-treated rat: basal activity and response to haloperidol. Brain Res 590:291-299.

Huguenard JR, Prince DA (1992) A novel T-type current underlies prolonged $\mathrm{Ca}^{2+}$-dependent burst firing in GABAergic neurons of rat thalamic reticular nucleus. J Neurosci 12:3804-3817.

Huguenard JR (1996) Low-threshold calcium currents in central nervous system neurons. Annu Rev Physiol 58:329-348.

Hutchison WD, Lozano AM, Tasker RR, Lang AE, Dostrovsky JO (1997) Identification and characterisation of neurons with tremor-frequency activity in human globus pallidus. Exp Brain Res 113:557-563.

Kreiss DS, Mastropietro CW, Rawji SS, Walters JR (1997) The response of subthalamic nucleus neurons to dopamine receptor stimulation in a rodent model of Parkinson's disease. J Neurosci 17:6807-6819.

Levy R, Hazrati LN, Herrero MT, Vila M, Hassani OK, Mouroux M, Ruberg M, Asensi H, Agid Y, Féger J, Obeso JA, Parent A, Hirsch EC (1997) Re-evaluation of the functional anatomy of the basal ganglia in normal and parkinsonian states. Neuroscience 76:335-343.

Limousin P, Pollak P, Benazzouz A, Hoffmann D, Le Bas JF, Broussolle E, Perret JE, Benabid AL (1995) Effect on parkinsonian signs and symptoms of bilateral subthalamic nucleus stimulation. Lancet 345:91-95.

Martin JP (1927) Hemichorea resulting from a local lesion of the brain (the syndrome of the body of Luys). Brain 50:637-651.

Martin LJ, Blackstone CD, Huganir RL, Price DL (1992) Cellular localization of a metabotropic glutamate receptor in rat brain. Neuron 9:259-270.

Matsumura M, Kojima J, Gardiner TW, Hikosaka O (1992) Visual and oculomotor functions of monkey subthalamic nucleus. J Neurophysiol 67:1615-1632.

Miller WC, DeLong MR (1987) Altered tonic activity of neurons in the globus pallidus and subthalamic nucleus in the primate MPTP model parkinsonian. In: The basal ganglia II (Carpenter MB, Jayaraman A, eds), pp 415-427. New York: Plenum.

Mink JW (1996) The basal ganglia: focused selection and inhibition of competing motor programs. Prog Neurobiol 50:381-425.

Nakanishi H, Kita H, Kitai ST (1987) Electrical membrane properties of rat subthalamic neurons in an in vitro slice preparation. Brain Res 437:35-44.

Nakanishi S (1994) Metabotropic glutamate receptors: synaptic transmission, modulation, and plasticity. Neuron 13:1031-1037.

Nini A, Feingold A, Slovin H, Bergman H (1995) Neurons in the globus pallidus do not show correlated activity in the normal monkey, but phase-locked oscillations appear in the MPTP model of parkinsonism. J Neurophysiol 74:1800-1805.

Overton PG, Greenfield SA (1995) Determinants of neuronal firing pattern in the guinea-pig subthalamic nucleus: an in vivo and in vitro comparison. J Neural Transm 10:41-54.

Overton PG, O’Callaghan JFX, Greenfield SA (1995) Possible intermixing of neurons from the subthalamic and substantia nigra pars compacta in the guinea-pig. Exp Brain Res 107:151-165.

Parent A, Hazrati LN (1995) Functional anatomy of the basal ganglia II. The place of subthalamic nucleus and external pallidum in basal ganglia circuitry. Brain Res Rev 20:128-154.

Pin JP, Duvoisin R (1995) The metabotropic glutamate receptors: structure and functions. Neuropharmacology 34:1-26.

Plenz D, Herrera-Marschitz M, Kitai ST (1997) The oscillatory feedback circuitry between subthalamic nucleus and globus pallidus as a putative generator for resting tremor. Soc Neurosci Abstr 23:181.2.

Prince DA, Connors BW (1986) Mechanisms of interictal epileptogenesis. In: Advances in neurology (Delgado-Escueta AV, Ward Jr AA, Woodbury DM, Porter RJ, eds), pp 275-299. New York: Raven.

Reuveni I, Friedman A, Amitai Y, Gutnick MJ (1993) Stepwise repolarization from $\mathrm{Ca}^{2+}$ plateaus in neocortical pyramidal cells: evidence for nonhomogeneous distribution of $\mathrm{HVA} \mathrm{Ca}^{2+}$ channels in dendrites. J Neurosci 13:4609-4621.

Rodriguez MC, Gorospe A, Mozo A, Guridi J, Ramos E, Linazasoro G, Obeso JA (1997) Characteristics of neuronal activity in the subthalamic nucleus (STN) and substantia nigra pars reticulata (SNr) in Parkinson's disease (PD). Soc Neurosci Abstr 23:183.6.

Russo RE, Nagy F, Hounsgaard J (1997) Modulation of plateau properties in dorsal horn neurones in a slice preparation of the turtle spinal cord. J Physiol (Lond) 499:459-474.

Sah P (1996) $\mathrm{Ca}^{2+}$-activated $\mathrm{K}^{+}$currents in neurones: types, physiological roles and modulation. Trends Neurosci 19:150-154.

Schrader LA, Tasker JG (1997) Modulation of multiple potassium currents by metabotropic glutamate receptors in neurons of the hypothalamic supraoptic nucleus. J Neurophysiol 78:3428-3437.

Song WJ, Otsuka T, Baba Y, Murakami F (1997) Characterization of $\mathrm{Ca}^{2+}$ currents in acutely isolated rat subthalamic nucleus neurons. Soc Neurosci Abstr 23:83.1.

Svirskis G, Hounsgaard J (1998) Transmitter regulation of plateau properties in turtle motoneurons. J Neurophysiol 79:45-50.

Testa CM, Standaert DG, Young AB, Penney Jr JB (1994) Metabotropic glutamate receptor mRNA expression in the basal ganglia of the rat. J Neurosci 14:3005-3018.

Testa CM, Friberg IK, Weiss SA, Standaert DG (1998) Immunohistochemical localization of metabotropic glutamate receptors mGluR1a and mGluR2/3 in the rat basal ganglia. J Comp Neurol 390:5-19.

Velumian AA, Zhang L, Pennafather P, Carlen PL (1997) Reversible inhibition of $\mathrm{I}_{\mathrm{K}}, \mathrm{I}_{\mathrm{AHP}}, \mathrm{I}_{\mathrm{h}}$ and $\mathrm{I}_{\mathrm{Ca}}$ currents by internally applied gluconate in rat hippocampal pyramidal neurones. Pflügers Arch 433:343-350.

Vila M, Levy R, Herrero M-T, Ruberg M, Faucheux B, Obeso JA, Agid Y, Hirsch E (1997) Consequences of nigrostriatal denervation on the functioning of the basal ganglia in human and nonhuman primates: an in situ hybridization study of cytochrome oxidase subunit I mRNA. J Neurosci 17:765-773.

Whittier JR, Mettler FA (1949) Studies of the subthalamus of the rhesus monkey. II. Hyperkinesia and other physiologic effects of subthalamic lesions, with special reference to the subthalamic nucleus of Luys. J Comp Neurol 90:319-372.

Wichmann T, Bergman H, DeLong MR (1994) The primate subthalamic nucleus I. Functional properties in intact animals. J Neurophysiol 72:494-506. 